\title{
Phencyclidine- and Dizocilpine-Induced Hyperlocomotion Are Differentially Mediated
}

\author{
Sven Ove Ögren, Dr.Med.Sc. and Menek Goldstein, M.D.
}

The dopamine (DA) $D_{2}$ agonist quinpirole and the $D_{2}$ receptor antagonists, haloperidol, raclopride, and remoxipride, were examined for their ability to block the locomotion induced by the noncompetitive N-methyl-Daspartate (NMDA) receptor antagonists phencyclidine $(P C P)$ and dizocilpine, both given in equipotent doses. Quinpirole, given in a "DA $D_{2}$ autoreceptor selective" dose $(0.01 \mathrm{mg} / \mathrm{kg})$, failed to influence the motor stimulation by PCP. On the other hand, the locomotor response induced by dizocilpine was significantly reduced by quinpirole. The three DA receptor antagonists blocked dose dependently the motor stimulation produced by both the low $(2 \mathrm{mg} / \mathrm{kg})$ and the high dose $(3 \mathrm{mg} / \mathrm{kg})$ of PCP. Haloperidol and remoxipride also blocked dose dependently and fully the stimulation produced by the low dose $(0.1 \mathrm{mg} / \mathrm{kg})$ of dizocilpine, whereas raclopride partially reduced the effect. The motor stimulation produced by the high doses of dizocilpine $(0.2 \mathrm{mg} / \mathrm{kg})$ and PCP $(3 \mathrm{mg} / \mathrm{kg})$ was reduced by haloperidol and raclopride only in cataleptogenic doses. Remoxipride, in contrast, fully blocked the effects of both PCP $(3 \mathrm{mg} / \mathrm{kg})$ and dizocilpine $(0.2 \mathrm{mg} / \mathrm{kg})$ in noncataleptogenic doses. These data suggest that different mechanisms of action may account for the motor stimulatory effects of PCP and dizocilpine. At the presynaptic level, PCP and dizocilpine may differ in the way they act on "regulatory" NMDA receptors controlling neuronal activity in midbrain neurons, and at the postsynaptic level they may interact with subtypes of NMDA receptors differentially coupled to subpopulations of $D_{2}$ receptors.

[Neuropsychopharmacology 11:167-177, 1994]
KEY WORDS: $D A D_{2}$ receptors; Glutamate; NMDA receptors; Phencyclidine; Dizocilpine; Haloperidol; Raclopride; Remoxipride

Evidence accumulated during the past decade has led to the suggestion that a deficiency in the action of the excitatory amino acid (EAA) glutamate may be part of the pathogenesis of schizophrenia (Kim et al. 1980; Deutch et al. 1989). This hypothesis is partly based on anatomical, pharmacological, and electrophysiological

From the Karolinska Institute, Department of Histology and Neurobiology (SOO), Stockholm, Sweden; and New York University Medical Center, School of Medicine (MG), New York, New York. Address correspondence to: Professor Sven Ove Ögren, Dr.Med.Sc., Karolinska Institute, Department of Histology and Neurobiology, Box 60400,10401 Stockholm, Sweden.

Received March 11, 1993; revised April 18, 1994; accepted June 2, 1994 findings suggesting that dopaminergic (DA) and glutamatergic neurons may interact reciprocally in structures of the brain implicated in schizophrenia, (e.g., in the dorsal and ventral striatum) (Kalivas et al. 1989; Imperato et al. 1990; Werling et al. 1990). Further evidence is provided by the observation that the dissociative anaesthetic phencyclidine (PCP), which interferes with glutamatergic neurotransmission in the brain, produces a syndrome in humans that is similar to schizophrenia (Luby et al. 1959; Javitt and Zukin 1991).

Systemic administration of PCP, which acts as a noncompetitive antagonist at the ion channel associated with the N-methyl-D-aspartate (NMDA) glutamate receptor (Lodge et al. 1988; Reid et al. 1990; Javitt and Zukin 1991), induces a complex behavioral syndrome. In low doses, the behavioral effects of PCP are characterized by enhanced locomotor activity and in higher doses by various types of stereotypies (head weaving, licking) usually accompanied by hind-limb ataxia (Sturgeon et al. 1979; Clineschmidt et al. 1982; Contreras et 
al. 1986; Wong and Kemp 1991). Although PCP affects several neurotransmitters, the behavioral and psychotominetic effects of PCP have been explained either as a result of NMDA receptor blockade (Johnston and Jones 1990; Javitt and Zukin 1991) or an indirect facilitation of dopaminergic (DA) transmission (French and Vantini 1984; French et al. 1985; Johnston 1987).

Several studies have suggested that the locomotor stimulation elicited by PCP, like that of d-amphetamine, may be mediated via enhancement of presynaptic mesolimbic DA transmission (French and Vantini 1984; French et al. 1991). For instance, lesion studies with 6-hydroxy-dopamine (6-OHDA) have shown that the PCP-induced motor stimulation depends at least partly on an intact mesolimbic DA system (French and Vantini 1984). Biochemical findings indicate also that PCP enhances presynaptic DA functions within the nucleus accumbens and striatum (French et al. 1985). Thus, PCP increases ${ }^{3} \mathrm{H}$-DA release in striatal slices (Snell et al. 1984), inhibits the neuronal uptake of DA (Javitt and Zukin 1991), and has also been shown to cause an increase in striatal and mesolimbic dihydroxyphenylacetic acid (DOPAC) and homovanillic acid (HVA) levels (Deutch et al. 1987; Chapman et al. 1990; Rao et al. 1990). Additional studies using in vivo microdialysis have shown that the extracellular DA concentrations in the nucleus accumbens and striatum are markedly increased after IP administration of PCP (Carboni et al. 1989; Lillrank et al. 1991). On the other hand, PCP and PCP-like drugs have been shown to enhance the firing rate in ventral tegmental $A_{10}$ neurons with a potency that was directly correlated to their affinity as noncompetitive NMDA receptor antagonists (French and Ceci 1990). Thus, these studies indicate that PCP may elicit hyperactivity via different mechanisms.

The physiological and behavioral effects of PCP are reported to be similar to those of the selective and noncompetitive NMDA antagonist dizocilpine (MK-801) (Koek et al. 1988; Tricklebank et al. 1989; Willetts et al. 1990), which binds with high selectivity to the open state of the NMDA receptor-coupled ion channel (Wong et al. 1986; Wong and Kemp 1991). Phencyclidine and dizocilpine affect DA neurons at the presynaptic level as they increase midbrain DA cell activity and DA neuronal firing rates (Freeman and Bunney 1984; French and Ceci 1990; Rao et al. 1990; Murase et al. 1993). Despite these similarities, the dopaminergic involvement behind the locomotor stimulation caused by dizocilpine is equivocal. Dopamine receptor antagonists acting at both the $\mathrm{D}_{1}$ and $\mathrm{D}_{2}$ receptors, which readily block the locomotor stimulation by $\mathrm{PCP}$, have been shown to block the locomotor stimulation by dizocilpine in some studies (Clineschmidt et al. 1982; Hoffman 1992; Ouagazzal et al. 1993) but not in others (Carlsson and Carlsson 1989; Raffa et al. 1989). Moreover, dizocilpine was found to cause locomotor stimulation in mono- mine-depleted mice via a monoamine-independent mechanism (Carlsson and Carlsson 1989), although this finding has recently not been confirmed (Goodwin et al. 1992).

Although dizocilpine, like $\mathrm{PCP}$, is reported to enhance DA functions in the brain (Liljequist et al. 1991; Clineschmidt et al. 1982) indicated by increased DA metabolism or turnover (Hiramatsu et al. 1989; Liljeqvist et al. 1991; Löscher et al. 1991; Murase et al. 1993), the evidence for an increase in DA release has remained inconclusive. Experiments in vitro with synaptosomes (Clineschmidt et al. 1982) and experiments with pushpull cannulae implanted in the vicinity of the striatum (Martin 1986) failed to show any effect of dizocilpine on DA release. Moreover, based on in vivo microdialysis in awake rats one study reported that when dizocilpine was infused through the probe it increased DA release in both the nucleus accumbens and the striatum (Imperato et al. 1990), whereas another microdialysis study in anaesthetized rats found that dizocilpine blocked the NMDA-induced increase in striatal DA release without producing any effect of its own (Morari et al. 1993). In freely moving rats, IP administration of dizocilpine $(0.25$ to $2 \mathrm{mg} / \mathrm{kg})$ reduced extracellular levels of DA and did not change the levels of DOPAC in the striatum (Kashihara et al. 1990).

The present series of experiments was designed to examine the dopaminergic mechanisms underlying the locomotor-stimulatory effect of PCP and dizocilpine. For this purpose we used low doses ( 2 and $3 \mathrm{mg} / \mathrm{kg}$ ) of PCP and dizocilpine $(0.1$ and $0.2 \mathrm{mg} / \mathrm{kg})$, which produce approximately equal increases in locomotor activity in the rat. A low-dose regimen is important because PCP in higher doses $(>5 \mathrm{mg} / \mathrm{kg})$ also influences serotonergic activity in the brain, which contributes to its behavioral effects (Hiramatsu et al. 1989). Moreover, although PCP, unlike dizocilpine, also has affinity for sigma binding sites, the affinity of PCP for the sigma site is less than one tenth of that for the NMDA receptor sites (see Javitt and Zukin 1991). Therefore, it seems unlikely in the doses used that PCP will exert a significant action on sigma receptor functions.

To analyze the role of pre- and postsynaptic DA receptor mechanisms, we studied whether the $D_{2}$ agonist quinpirole or the $\mathrm{DA} \mathrm{D}_{2}$ antagonists haloperidol (Hyttel 1978), remoxipride and raclopride (Ögren et al. 1984; 1986; Köhler et al. 1985) could differentially block the locomotor stimulatory effects induced by PCP and dizocilpine. Quinpirole (LY171, 555) has been shown to be a highly selective agonist of the DA $D_{2}$ receptor both in vitro and in vivo (Tsuruta et al. 1981; Titus et al. 1983). When given at low doses, quinpirole preferentially stimulates $\mathrm{DA}_{2}$ autoreceptors and thereby reduces the firing of DA cells in the substantia nigra pars compacta and the ventral tegmental area (Carlson et al. 1987). Both remoxipride and raclopride 
are highly selective $D_{2}$ receptor antagonists both in vitro and in vivo (Ögren et al. 1984, 1990; Köhler et al. 1985), whereas haloperidol is a preferential $D D_{2}$ antagonist, which in high doses also blocks $\mathrm{DA}_{1}$ receptors (Christensen et al. 1984).

\section{METHODS}

\section{Animals}

Male Sprague-Dawley rats (A-Lab, Sollentuna, Sweden) weighing 240 to $300 \mathrm{~g}$ at the start of the experiments were housed in groups of four in type IV Macrolon cages with free access to pellets and water. They were kept under standardized laboratory conditions (temperature $21 \pm 1^{\circ} \mathrm{C}, 40$ to $50 \%$ humidity) and light conditions with a 12-hour light/dark cycle (light on at 07.00 hours).

\section{Compounds}

The following test compounds were used: quinpirole hydrochloride (LY171,555), the levoratory isomer of LY141,865 [trans-4,4a, 5, 6,7,8,8a,9-octahydro-5-propyl$1 \mathrm{H}$ (or $2 \mathrm{H}$ )-pyrazolo[3,4-g]quinoline, (Eli Lilly, Indianapolis) was dissolved in saline $(0.9 \% \mathrm{NaCl})(\mathrm{pH} 6)$; raclopride (Astra Arcus $\mathrm{AB}$, Södertälje, Sweden) $(\mathrm{pH}$ $\sim 5$ ) and remoxipride hydrochloride monohydrate (Astra Arcus $\mathrm{AB}$ ) ( $\mathrm{pH} \sim 5.5)$ were dissolved in saline; haloperidol (Sigma, St Louis, MO), was dissolved in a few drops of acetic acid and distilled water, and the $\mathrm{pH}$ of the solution was adjusted to $\mathrm{pH} 4$ to 5 using $\mathrm{NaOH}$. Dizocilpine (MK-801) [(+)-5-methyl-10,11dihydro-5H-dibenzo[a, d]cyclohepten-5,10-imine maleate] (Sigma) and phencyclidine hydrochloride (PCP) (Sigma) were both dissolved in saline. The test compounds were injected SC into the neck in a volume of $2 \mathrm{ml} / \mathrm{kg}$ or in a volume of $5 \mathrm{ml} / \mathrm{kg}$ IP.

\section{Experimental Design}

The behavioral testing was performed between 08.00 and 15.00 hours during the light period. The rats were only used once, and eight rats were randomly assigned to each treatment group. In each set of experiments, concurrent controls were always used and treated either with saline or PCP/dizocilpine. The rats were first accustomed to the experimental room for at least 30 minutes prior to the experiment and then placed individually in the locomotor cages for an additional 40 minutes' habituation period. Following the injection of $\mathrm{PCP}$ or dizocilpine, the rats were again placed in the locomotor cages. In most studies, locomotion was recorded for a period of 60 minutes after PCP injection and 120 minutes after injection of dizocilpine. Due to differences in the temporal effects of the two compounds (Figure 1), the periods 0 to 60 minutes after PCP
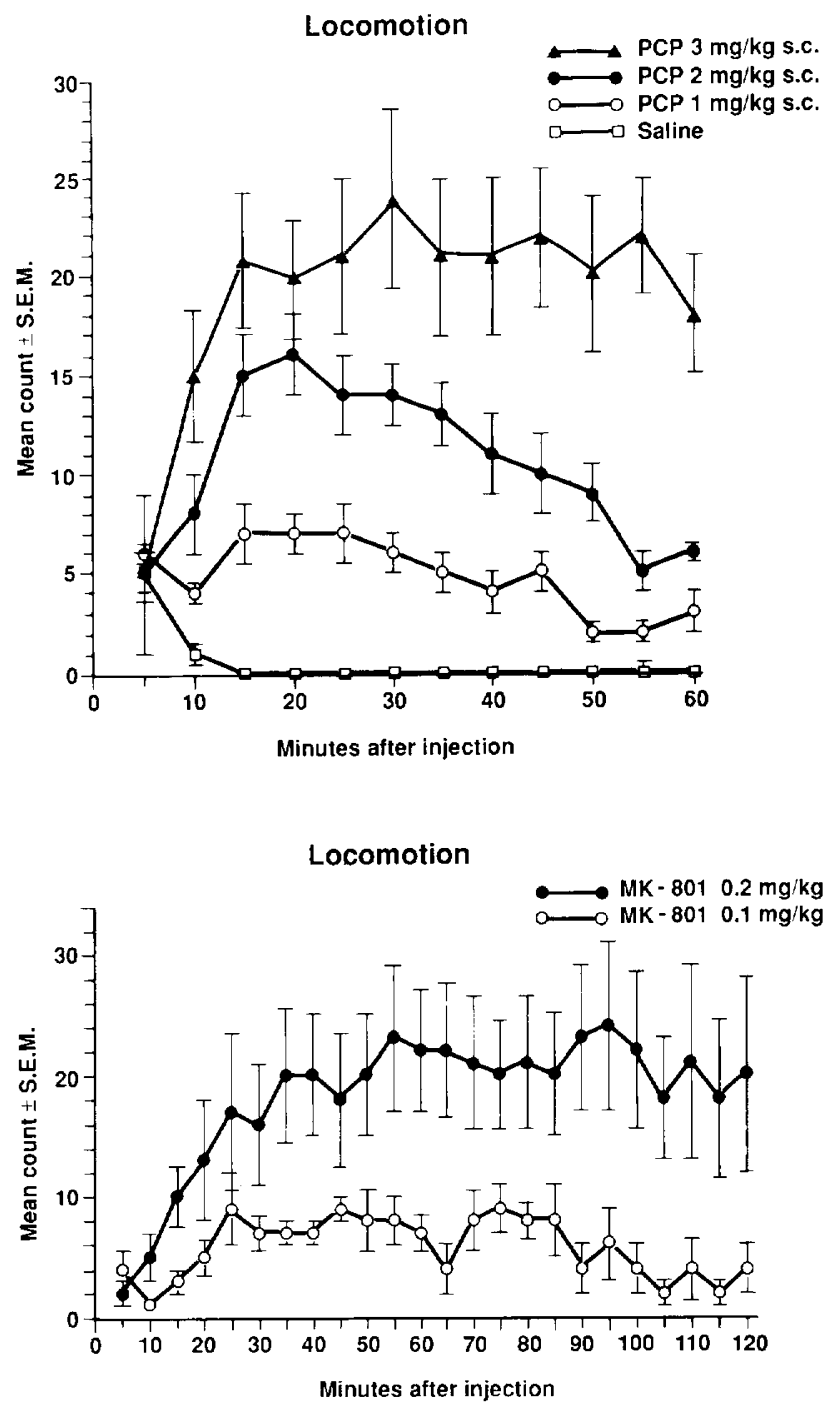

Figure 1. The temporal effects of PCP and dizocilpine on locomotion. Groups of 8 to 12 male rats were habituated for a period of 40 minutes in the locomotor cages. Following SC injection of $\operatorname{PCP}(1,2$, and $3 \mathrm{mg} / \mathrm{kg})$, dizocilpine $(0.1$ and 0.2 $\mathrm{mg} / \mathrm{kg}$ ) or saline $(2 \mathrm{ml} / \mathrm{kg})$, the rats were again placed in the locomotor cages. Locomotor activity was recorded for a 60 minute period after PCP and for a 120 -minute period after dizocilpine. The results show the mean values \pm SEM for each 5-minute measurement period following injection of PCP or dizocilpine. The following mean counts \pm SEM were obtained for the accumulated 60-minute recording period for PCP: 1 $\mathrm{mg} / \mathrm{kg}=56 \pm 7.5 ; 2 \mathrm{mg} / \mathrm{kg}=124 \pm 13.5 ;$ and $3 \mathrm{mg} / \mathrm{kg}=$ $229 \pm 36$. The mean values for the 20 - to 80 -minute period of recording, (e.g., 60-minute) recording period for dizocilpine were: $0.1 \mathrm{mg} / \mathrm{kg}=94 \pm 17 ; 0.2 \mathrm{mg} / \mathrm{kg}=251 \pm 63$.

injections and 20 to 80 minutes after dizocilpine injections were used for the subsequent statistical analysis.

Locomotion, motility, and rearing were recorded simultaneously in twelve computerized locomotor cages (Motron Products, Sweden) as described previously (Ögren et al. 1979). The behavioral effects of the 
treatment were assessed and sniffing, ataxia, oral stereotypies, and head-weaving were scored. In addition, the ability of the DA antagonists to induce catalepsy in the bar test was examined as described elsewhere (Ögren et al. 1994a).

One- and two-factor analysis of variances was used to determine $F$ ratios and levels of significance of drug effects in the dose response studies. Post hoc analyses were conducted by Student's $t$-test or Dunnett's test when appropriate. Multiple group comparisons were performed using the Fisher's PLSD test. The dosedependency was evaluated by the Jonckheere-Terpstra trend test (Hollander and Wolfe 1973).

\section{RESULTS}

The rats were acclimatized both to the experimental room and to the locomotor cages prior to the experiment to be able to study the locomotor response without interference with spontaneous locomotion. Figure 1 shows that this acclimatization procedure resulted in a very low level of exploratory locomotion in the control group receiving saline. After the saline injection, only a small locomotor response was observed during the first 5 minutes of recording indicating an efficient acclimatization to the locomotor cages.

Both PCP $(1,2$, and $3 \mathrm{mg} / \mathrm{kg})$ and dizocilpine (0.1 and $0.2 \mathrm{mg} / \mathrm{kg}$ ) were found to produce a dosedependent increase in both locomotion and motility while rearing activity was suppressed (only data on locomotion are shown). Figure 1 shows that the locomotor stimulatory effects of dizocilpine and PCP differed with respect to time. Thus, the peak effect after PCP was seen after 15 to 25 minutes followed by a gradual decrease. The increase in locomotor activity after dizocilpine was gradual and reached a steady-state level after around 60 minutes at the $0.2 \mathrm{mg} / \mathrm{kg}$ dose.

The accumulated counts for a 60 -minute locomotor recording period were chosen as the measure of the effectiveness for dizocilpine and PCP. Dizocilpine was found to be approximately 15 times more potent than $\mathrm{PCP}$ in inducing locomotion based on the 60-minute period of recording ( 0 to 60 minutes after PCP injections and 20 to 80 minutes after dizocilpine injections) (see legend of Figure 1). This means that the $0.2 \mathrm{mg} / \mathrm{kg}$ dose of dizocilpine was equipotent with the $3 \mathrm{mg} / \mathrm{kg}$ dose of PCP, whereas the $0.1 \mathrm{mg} / \mathrm{kg}$ dose of dizocilpine was approximately equipotent with the $2 \mathrm{mg} / \mathrm{kg}$ dose of PCP.

The $0.1 \mathrm{mg} / \mathrm{kg}$ dose of dizocilpine produced repetitive, stereotyped behaviors such as sniffing, signs of ataxia, and head-bobbing, but no apparent oral stereotypies or head-weavings. With the $0.2 \mathrm{mg} / \mathrm{kg}$ dose, these behavioral symptoms were more pronounced, and some animals displayed loss of righting reflexes.
Unlike dizocilpine, PCP in a dose of $2 \mathrm{mg} / \mathrm{kg}$ caused no signs of ataxia or head-bobbing, whereas the $3 \mathrm{mg} / \mathrm{kg}$ dose of PCP exhibited stereotypies with a pattern similar to that of the $0.2 \mathrm{mg} / \mathrm{kg}$ dose of dizocilpine, with the exception that no loss of righting reflexes was observed.

The $D_{2}$ receptor agonist quinpirole was examined for its ability to modify the locomotor stimulation induced by PCP and dizocilpine. Although the effect is seemingly small due to the use of habituated rat, Figures 2 and 3 show that quinpirole $(0.01 \mathrm{mg} / \mathrm{kg})$ suppressed the basal motor activity by approximately $50 \%$ compared to the control group. Quinpirole did not alter the motor stimulation caused by PCP because the two-factor
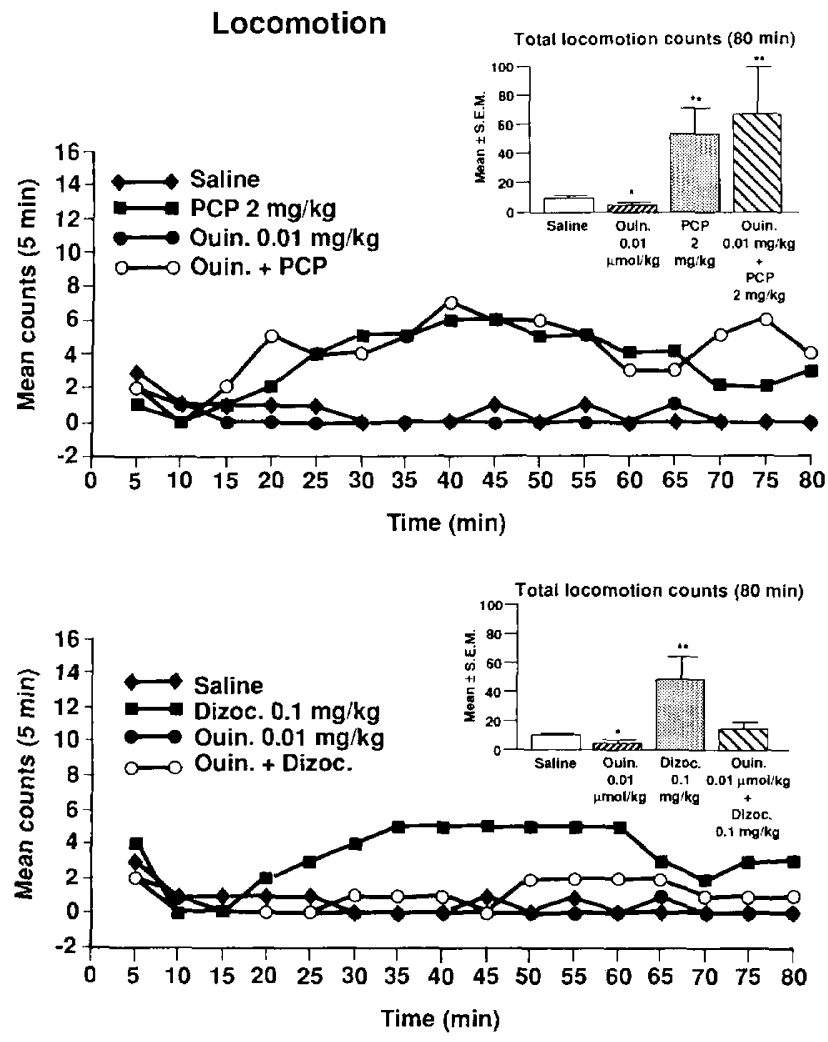

Figure 2. The effects of pretreatment with quinpirole on the locomotor response induced by the low doses of PCP $(2 \mathrm{mg} / \mathrm{kg}$ $\mathrm{SC})$ and dizocilpine $(0.1 \mathrm{mg} / \mathrm{kg} \mathrm{SC})$. Separate groups of rats ( $n=8$ /group) were pretreated with the DA agonist quinpirole $(0.01 \mathrm{mg} / \mathrm{kg} \mathrm{SC})$ or saline $(2 \mathrm{ml} / \mathrm{kg} \mathrm{SC}) 10$ minutes prior to the injection of PCP or dizocilpine. Locomotion was measured for a period of 0 to 80 minutes after the two NMDA-receptor antagonists using the design presented in Figure 1. The results show the mean values of the four treatment conditions for each consecutive 5 -minute measurement period. The insert shows the mean total locomotion counts \pm SEM statistical analysis during the 80 minutes following PCP or dizocilpine injections. Statistical analysis was performed by ANOVA followed by Dunnett's multiple $t$-test: * $p<.05,{ }^{*}{ }^{*} p<.01$ versus the saline control group. 

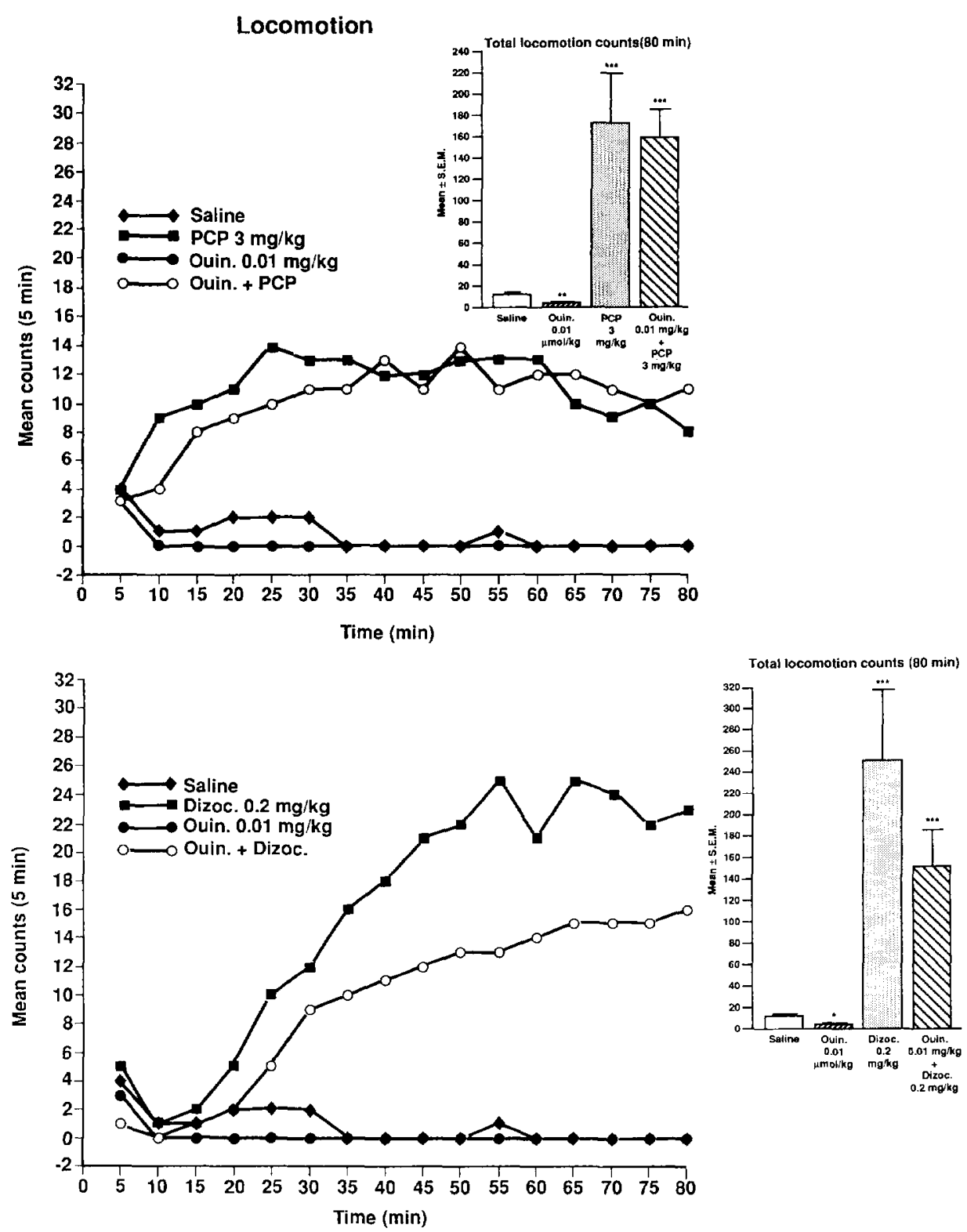

Figure 3. The effects of pretreatment with quinpirole on the locomotor response induced by the high doses of PCP $(3 \mathrm{mg} / \mathrm{kg}$ $\mathrm{SC})$ and dizocilpine $(0.2 \mathrm{mg} / \mathrm{kg}$ $\mathrm{SC})$. Separate groups of rats ( $n=8$ /group) were pretreated with the DA agonist quinpirole $(0.01 \mathrm{mg} / \mathrm{kg} \mathrm{SC})$ or saline $(2 \mathrm{ml} /$ $\mathrm{kg} \mathrm{SC)} 10$ minutes prior to the injection of PCP or dizocilpine. Locomotion was measured for a period of 0 to 80 minutes after the two NMDA-receptor antagonists. For further details, see legend of Figure 2. The insert shows the mean total locomotion counts.

ANOVA revealed no significant main effect of treatment (Figures 2 and 3), and the multiple comparison test failed to show any difference between the quinpirole + PCP tested groups versus the PCP treated groups $(p>.50)$. In contrast, quinpirole attenuated the locomotor stimulation by dizocilpine. Thus, the two-factor ANOVA revealed a significant $(p<.01)$ effect of treatment. Multiple comparisons using Fisher's PLSD test revealed that quinpirole significantly reduced the effect of dizocilpine given at both low $(p<.001)$ and high $(p<.07)$ dizocilpine doses (Figures 2 and 3).

The three DA receptor antagonists produced a dose-dependent ( $p<.001$, Jonckheere's trend test) and complete blockade of PCP-induced locomotion given at $2 \mathrm{mg} / \mathrm{kg}$ (Figure 3). With a dose of $0.3 \mu \mathrm{mol} / \mathrm{kg}$, haloperidol and raclopride reduced the effect of the
$2 \mathrm{mg} / \mathrm{kg}$ dose of PCP by approximately 60 to $70 \%$, whereas doses in the range of 1 to $3 \mu \mathrm{mol} / \mathrm{kg}$ were required for a total blockade of the stimulatory effect of PCP. The corresponding doses for remoxipride were 3 and $40 \mu \mathrm{mol} / \mathrm{kg}$, respectively. Haloperidol and raclopride also caused a dose-dependent $(p<.001)$ blockade of the locomotion induced by the $3 \mathrm{mg} / \mathrm{kg}$ dose of PCP (Figure 4). However, cataleptogenic doses of both haloperidol and raclopride were required for a 60 to $80 \%$ inhibition of the effect by PCP. The PCP-induced locomotion was dose dependently $(p<.001)$ reduced by remoxipride in a manner different from that of raclopride. Thus, the two highest doses of remoxipride (10 and $40 \mu \mathrm{mol} / \mathrm{kg}$ ) almost completely blocked ( 80 to $100 \%$ inhibition) the effects of both the 2 and $3 \mathrm{mg} / \mathrm{kg}$ doses of PCP. 

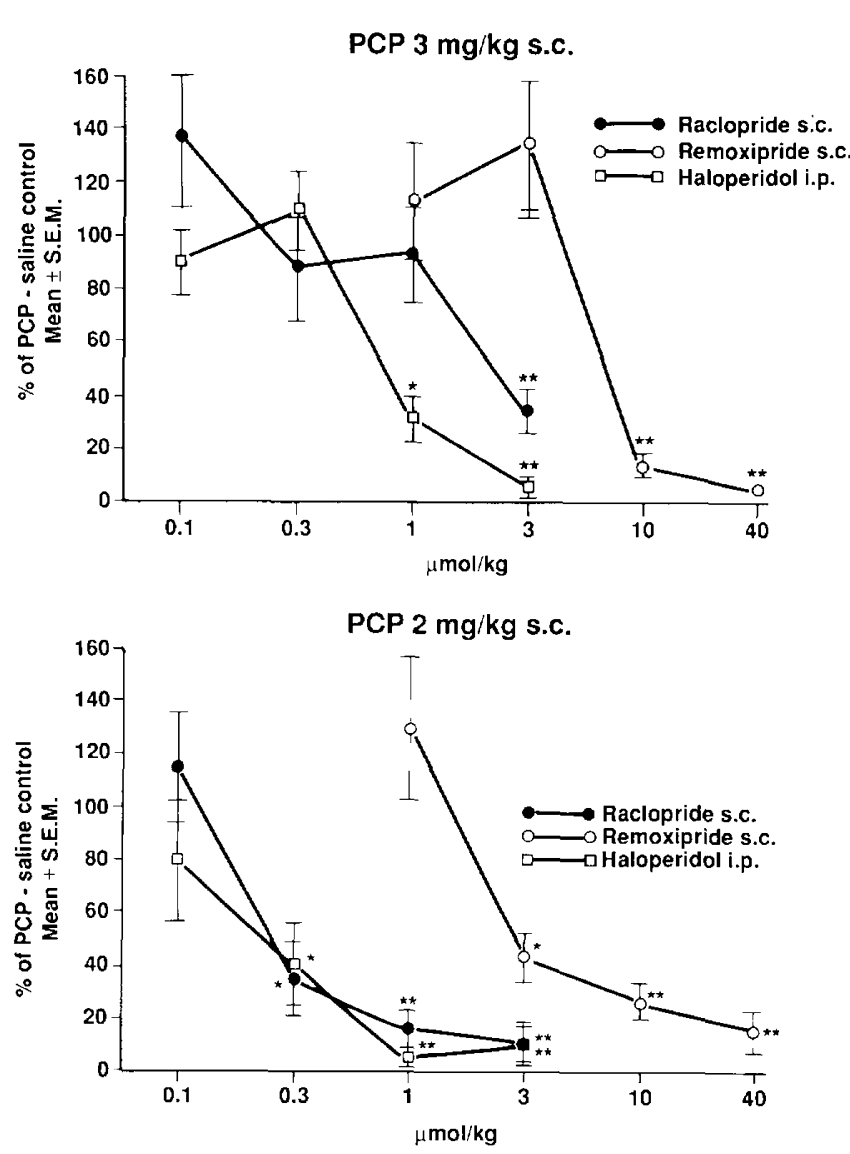

Figure 4. Effects of haloperidol, raclopride, and remoxipride on locomotion induced by PCP ( 2 and $3 \mathrm{mg} / \mathrm{kg} \mathrm{SC}$ ). Separate groups of rats ( $n=8$ /group) received IP administration of haloperidol or saline 30 minutes prior to the injection of PCP. In separate experiments, raclopride and remoxipride were given SC 10 minutes and 30 minutes, respectively, prior to the injection of PCP. Locomotion was measured for a period of 0 to 60 minutes after PCP. The results show the mean values of the integrated motor response \pm SEM as percentages of values in the concurrent PCP-saline control groups. Statistical analysis was performed by ANOVA followed by individual group comparisons versus the concurrent $P C P$-control group using Dunnett's multiple $t$-test: ${ }^{*} p<.05,{ }^{* *} p<.01$ versus the PCP control groups.

Both haloperidol and remoxipride caused a dosedependent $(p<.001)$, complete blockade of the dizocilpine-induced locomotion $(0.1 \mathrm{mg} / \mathrm{kg})$ (Figure 5$)$, whereas raclopride in the range 0.3 to $3 \mu \mathrm{mol} / \mathrm{kg}$ partially reduced the locomotor stimulation. A cataleptogenic dose of haloperidol and raclopride $(1 \mu \mathrm{mol} / \mathrm{kg})$ was required to reduce the locomotor stimulative effect of the high dizocilpine dose $(0.2 \mathrm{mg} / \mathrm{kg})$ with approximately $60 \%$. In contrast, the 1 to $10 \mu \mathrm{mol} / \mathrm{kg}$ doses of remoxipride tended to enhance, whereas the 40 $\mu \mathrm{mol} / \mathrm{kg}$ dose completely blocked $(p<.01)$ the locomotor stimulation produced by the $0.2 \mathrm{mg} / \mathrm{kg}$ dose of dizocilpine. It is notable that the dose-response curves
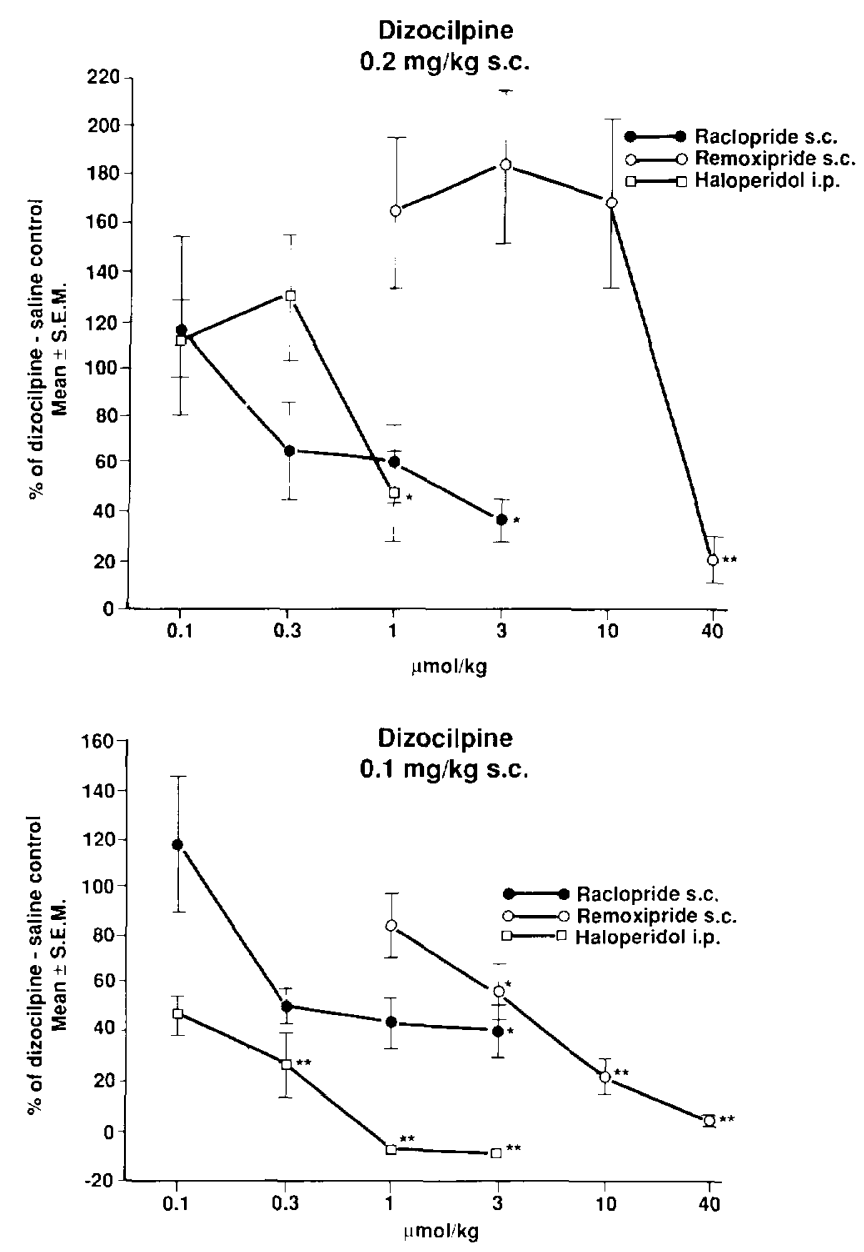

Figure 5. Effects of haloperidol, raclopride, and remoxipride on locomotion induced by dizocilpine $(0.1$ and $0.2 \mathrm{mg} / \mathrm{kg} \mathrm{SC})$. Separate groups of rats ( $n=8$ /group) received IP administration of different doses of haloperidol or saline 30 minutes prior to the injection of dizocilpine. In separate experiments, raclopride and remoxipride were given SC 10 minutes and 30 minutes respectively, prior to the injection of dizocilpine. Locomotion was measured for a period of 20 to 80 minutes after dizocilpine. The results show the mean values of the integrated motor response \pm SEM as percentages of values in the concurrent dizocilpine-saline control groups. Statistical analysis was performed by ANOVA followed by Dunnett's multiple $t$-test (in the case of the $40 \mu \mathrm{mol} / \mathrm{kg}$ dose of remoxipride versus the $0.3 \mathrm{mg} / \mathrm{kg}$ dose of dizocilpine, Student's $t$-test was used): ${ }^{*} p<.05,{ }^{* *} p<.01$ versus the dizocilpine control groups.

of raclopride are flat and the maximal degree of inhibition of locomotor stimulation was in the range ( 40 to $60 \%$ ) for both doses of dizocilpine.

To examine whether the effects on locomotion were related to a nonspecific suppression of locomotor activity, the DA receptor antagonists were tested for their ability to induce catalepsy in the horizontal bar test. As shown in Figure 6, both haloperidol and raclopride caused a dose-dependent cataleptic effect $\left(E_{50} \sim 1\right.$ 


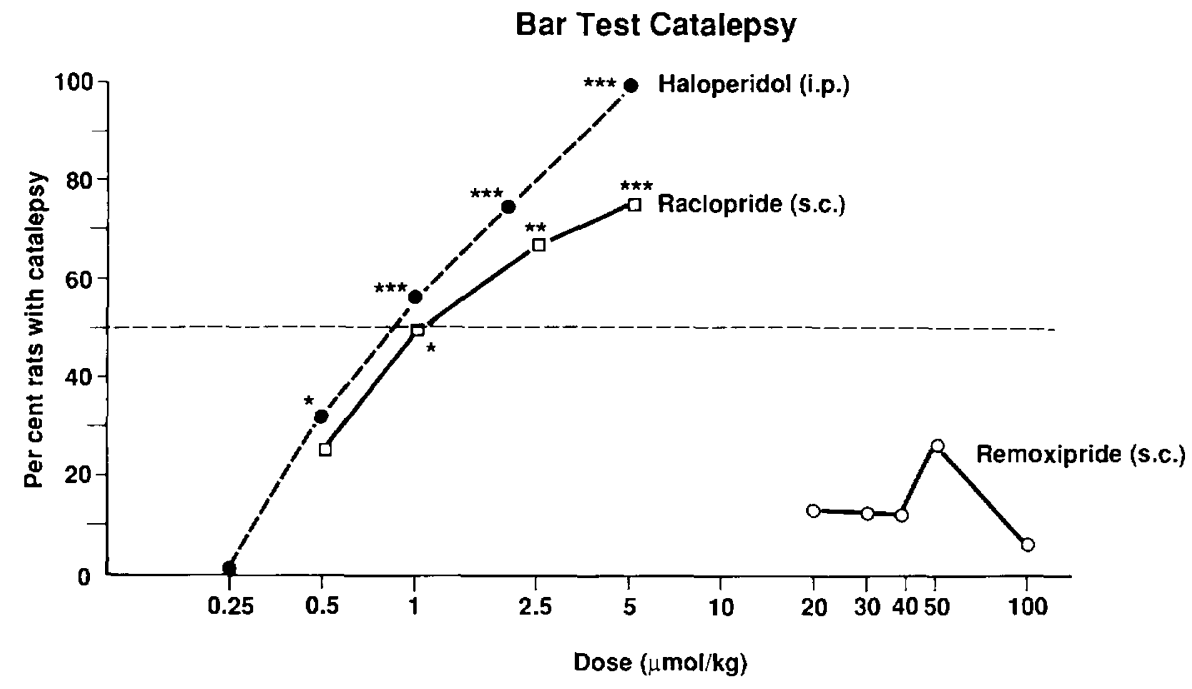

Figure 6. Cataleptic potency of the tested compounds assessed using the bar test. Groups ( $n=8$ to 16/group) of rats were examined for bar test catalepsy $20,40,60,90,120$, and 240 minutes after administration. The statistical analysis was performed using Fischer's exact test, comparing the proportion of animals that reached a mean value of descent latency of $\geqslant 15$ seconds (the definition for catalepsy) on the three test occasions showing peak effects of response with a saline control. The dotted line indicates the level where $50 \%$ of the animals are cataleptic according to this criterion. Significance levels: ${ }^{*} p<.05,{ }^{* *} p<.01,{ }^{* * *} p<.001$. $\mu \mathrm{mol} / \mathrm{kg}$ ). Remoxipride, on the other hand, displayed a flat dose-response curve and failed to produce a significant cataleptic effect in the dose range 20 to 100 $\mu \mathrm{mol} / \mathrm{kg} \mathrm{SC}$.

\section{DISCUSSION}

These results confirm earlier findings showing that NMDA receptor blockade by noncompetitive antagonists can produce a dose-dependent stimulation of locomotor activity (locomotion and motility) (Johnston 1987; Ford et al. 1989) similar to that observed after facilitation of dopaminergic neurotransmission. Both PCP and dizocilpine, however, reduced rearing activity, indicating that the effects of noncompetitive NMDA-receptor blockade are only partly similar to the effects observed after indirectly acting DA agonists (e.g., d-amphetamine, which increases rearing activity).

The locomotor effects of PCP and dizocilpine differed in their potencies and time for peak effect. Dizocilpine was approximately 15 times more effective than PCP, which corresponds roughly with their respective affinities ( $K_{d}$ values) for the NMDA channel binding site (see Javitt and Zukin 1991), indicating that their primary site of action is via NMDA-receptor blockade. The late onset of the behavioral action of dizocilpine is difficult to explain but suggests that PCP and dizocilpine differ in their temporal association to the NMDA receptor channel.

The major finding of this study is that the locomotion response induced by PCP and dizocilpine can be distinguished on the basis of their differential sensitivity to quinpirole and $\mathrm{DA}_{2}$ receptor antagonists. The $\mathrm{D}_{2}$ agonist quinpirole, given in a dose that preferentially stimulates DA autoreceptors, failed to attenuate the locomotor effect by PCA, whereas it significantly reduced the effect of dizocilpine. In addition, the $\mathrm{D}_{2}$ antagonists haloperidol, remoxipride, and raclopride blocked the locomotor activity induced by both PCP and dizocilpine. Haloperidol and remoxipride blocked dose dependently the motor stimulation caused by the low $(0.1 \mathrm{mg} / \mathrm{kg})$ dizocilpine dose, whereas raclopride produced a partial inhibition. The motor stimulation caused by the high dizocilpine dose $(0.2 \mathrm{mg} / \mathrm{kg})$ was reduced by haloperidol and raclopride only at doses that were cataleptogenic (see Figure 5). In contrast, remoxipride tended to enhance the locomotor stimulation by the high dizocilpine dose in the dose range 1 to $10 \mu \mathrm{mol} / \mathrm{kg}$, whereas the remoxipride dose $40 \mu \mathrm{mol} / \mathrm{kg}$ completely blocked the motor stimulatory effect. It is notable that this dose of remoxipride did not induce catalepsy. All three $D_{2}$ antagonists dose dependently blocked the induced locomotion caused by the low $(2 \mathrm{mg} / \mathrm{kg})$ PCP dose. Haloperidol and raclopride significantly reduced the locomotion induced by the high PCP dose $(3 \mathrm{mg} / \mathrm{kg}$ ) only at cataleptogenic doses, whereas remoxipride effectively blocked the high dose response by PCP without causing catalepsy. Taken together, these results suggest that the mechanisms underlying the behavioral effects of locomotor stimulation of PCP and dizocilpine differ

The differential blockade of the locomotor stimulation by these $D_{2}$ antagonists tested could not be explained by a nonspecific, suppressive effect on motor performance because both haloperidol and raclopride produced a dose-dependent cataleptic effect, whereas remoxipride did not produce catalepsy in the dose range tested (see below). Moreover, the ability of the tested DA antagonists to suppress spontaneous locomotor activity agrees well with their dose-dependent cataleptic effects (Ögren et al. 1994a).

The observation that the motor stimulation by PCP was not reduced by quinpirole suggests that the action 
of dizocilpine, but not that $\mathrm{PCP}$, involves a mechanism regulated by $\mathrm{D}_{2}$ autoreceptors. At the dose used, quinpirole reduced spontaneous locomotor activity by approximately $50 \%$, presumably by stimulation of autoreceptors of the $\mathrm{D}_{2}$ type (see Ståhle 1992). Stimulation of $\mathrm{DA} \mathrm{D}_{2}$ receptors (autoreceptors) located on DA neurons will lead to effects characteristic of reduced DA transmission, such as decreases in firing rates of both nigrostriatal and mesoaccumbens DA neurons (Carlson et al. 1987) as well as decreases in DA release in vivo (See et al. 1991). Whether the differences of PCP or dizocilpine may partly depend on a differential modulation of discrete populations of DA neurons in the brainstem or in the DA terminals differentially sensitive to $D_{2}$ autoregulation remains to be studied. However, it is notable that, unlike dizocilpine, PCP produces a bimodal, dose-dependent increase-decrease in the firing rate of midbrain DA neurons at behaviorally relevant doses (Freeman and Bunney 1984; French and Ceci 1990; French et al. 1991). Moreover, PCP and dizocilpine exert differential effects on the firing patterns (firing rate versus burst firing) in the substantia nigra and ventral tegmental area (Pawlowski et al. 1990; Murase et al. 1993).

An alternative interpretation is based on the recent finding that quinpirole binds with a 100 -fold higher affinity to the $D_{A} D_{3}$ receptor than to the $D_{2}$ receptor (Lévesque et al. 1992). Because the $\mathrm{DA}_{3}$ receptor appears to play an inhibitory role in the control of locomotion (Daly and Waddington 1992), like the $\mathrm{D}_{2}$ receptor (see Stăhle 1992), it is possible that dizocilpine, unlike PCP, may antagonize the (postsynaptic) $\mathrm{DA} \mathrm{D}_{3}$ receptor population activated by quinpirole.

Some of the motor stimulating effects of PCP and dizocilpine are most likely mediated via increases in firing rates of DA neurons in the substantia nigra and ventral tegmental area subsequent to NMDA-receptor blockade (Freeman and Bunney 1984; French and Ceci 1990). The failure to detect any increased extracellular accumulation of DA in most in vivo studies after dizocilpine (see Introduction) despite increase in DA neuronal activity may seem paradoxical but is probably due to the negligible effect of dizocilpine on the uptake and release mechanisms of DA (Johnston and Jones 1990). However, because the effect of PCP on neuronal firing is combined with direct effects on the DA release and uptake mechanisms (see Introduction), PCP injections will result in detectable increases in extracellular DA.

The blockade of the effects of dizocilpine and PCP by the $\mathrm{D}_{2}$ antagonists tested indicate that the hyperactivity induced by both PCP and dizocilpine is dependent upon dopaminergic mechanisms and that postsynaptic DA $D_{2}$ receptors play an important role in its mediation. However, the differential blockade of the effects of dizocilpine and PCP by the $\mathrm{D}_{2}$ antagonists tested indicate that these two NMDA antagonists differ with regard to their interaction with postsynaptic DA receptors. A high degree of $\mathrm{DA} \mathrm{D}_{2}$ blockade (resulting in catalepsy after haloperidol and raclopride) is required to completely eliminate the stimulative action of the high doses of PCP or dizocilpine. This indicates that approximately 80 to $90 \%$ of the $\mathrm{DA} \mathrm{D}_{2}$ receptors in several regions (e.g., both the striatum, the nucleus accumbens, and in the forebrain) have to be occupied following haloperidol and raclopride (see Köhler et al. 1985, 1992) to effectively antagonize the locomotor responses to high doses of PCP and dizocilpine. This interpretation is consistent with the observation that a 6-OHDAinduced depletion of accumbens DA by approximately $80 \%$ partially blocked (approximately $50 \%$ inhibition) the locomotor response to PCP (French et al. 1991) but failed to affect the response to dizocilpine (Ouagazzal et al. 1993). These findings indicate that the hyperactivity caused by PCP and dizocilpine is mediated by disparate and multiple mechanisms. The observation that remoxipride, unlike raclopride and haloperidol, can block the high-dose locomotor responses of both dizocilpine and PCP at dose levels that do not cause catalepsy or suppression of spontaneous locomotion (see Ögren et al. 1990, 1994a) is also intriguing. This finding suggests that remoxipride may affect dopamine-glutamate receptor interactions in a manner that differs from other DA $D_{2}$ receptor antagonists, probably by acting on subtypes of $\mathrm{DA} \mathrm{D}_{2}$ receptors (see Ögren et al. 1994b).

The different results obtained in the PCP- and dizocilpine-model with haloperidol, raclopride, and remoxipride are unexpected in view of their high selectivity for $D A D_{2}$ receptors and negligible effects on nondopaminergic receptors (Hall et al. 1986), including the NMDA receptor binding sites (to be published). The different findings for remoxipride and raclopride may reflect actions on subtypes of $D A D_{2}$ receptors, because their DA receptor blocking properties exhibit similar but not identical patterns (see Ögren et al. 1986, 1990, 1994b). For instance, raclopride and haloperidol have approximately equal affinity for the "human" DA $D_{2}$ and $D_{3}$ receptors, whereas remoxipride has much lower affinity for the $\mathrm{D}_{3}$ than for the $\mathrm{D}_{2}$ receptors (Sokoloff et al. 1992; Mohell et al. 1993).

It has been suggested that the behavioral syndrome induced by PCP represents an animal model of schizophrenia (Tiedtke et al. 1990; Javitt and Zukin 1991) based on the conjecture that reduced glutamate neurotransmission at the NMDA receptors is directly or indirectly related to the symptoms of the psychotic state (see McKinney 1989). In this context, the present data suggest that the clinical efficacy of both typical (haloperidol) and atypical antipsychotic drugs (remoxipride) may in part be mediated by indirect modulation of glutamate transmission via DA receptors (see Hoffman 1992). However, given the possible importance of this model for schizophrenia, the different results obtained for 
quinpirole and the $\mathrm{D}_{2}$ antagonists in the PCP model are intriguing. These findings, therefore, suggest that compounds acting as agonists at the $\mathrm{D}_{2}$ autoreceptors may not have antipsychotic properties.

In conclusion, these results indicate that dopaminergic neurotransmission plays an essential role in the hypermotility response to $\mathrm{PCP}$ and dizocilpine and that this response requires the activation of $D A D_{2}$ receptors. Different glutamatergic and dopaminergic interactions at both the pre- and postsynaptic levels could explain the mode of action behind the motor stimulation by PCP and dizocilpine. The differences between PCP and dizocilpine indicate that they affect partly different types of "regulatory" NMDA receptors that control the neuronal activity in populations of midbrain DA neurons. These neuronal groups are probably differentially regulated by subtypes of $D_{2}$ receptors. The variation in the effects of the DA $D_{2}$ antagonists tested suggests that PCP and dizocilpine also differ with respect to the manner by which they influence the interactions between $\mathrm{DA} \mathrm{D}_{2}$ and glutamate transmission postsynaptic to the DA terminals. In view of the molecular diversity of glutamate receptors (Gasic and Hollmann 1992), it is possible that dizocilpine and PCP may interact at the postsynaptic membrane with different subpopulations of NMDA receptors (see Monaghan et al. 1989) with differential coupling to DA $D_{2}$ receptors.

\section{ACKNOWLEDGMENTS}

We thank Ms. Susanne Andersson for excellent technical assistance and Mrs. Birgitta Olofsson for typing the manuscript.

\section{REFERENCES}

Carboni E, Imperato A, Perezzain L, Di Chiara G (1989): Amphetamine, cocaine, phencyclidine and nomifensine increase extra-cellular dopamine concentrations preferentially in the nucleus accumbens of freely moving rats. Neuroscience 28:653-661

Carlson JH, Bergström DA, Walters JR (1987): Stimulation of both $D_{1}$ and $D_{2}$ dopamine receptors appears necessary for full expression of postsynaptic effects of dopamine agonists: A neurophysiological study. Brain Res 400: 205-218

Carlsson M, Carlsson A (1989): The NMDA antagonist MK801 causes marked locomotor stimulation in monoaminedepleted mice. J Neural Transm 75:221-226

Chapman CD, Gazarra RA, Howard SG (1990): Effects of phencyclidine on extracellular levels of dopamine, dihydroxyphenylacetic acid and homovanillic acid in conscious and anesthetized rats. Neuropharmacology 29:319-325

Christensen AV, Arnt J, Hyttel J, Larsen JJ, Svendsen O (1984): Pharmacological effects of a specific dopamine $D_{1}$ an- tagonist SCH 23390 in comparison with neuroleptics. Life Sci 34:1529-1540

Clineschmidt BV, Martin GE, Bunting PR (1982): Anticonvulsant activity of (+)-5-methyl-10,11-dihydro-5H-dibenzo[a,d]cyclohepten-5-10-imine (MK-801), a substance with potent anticonvulsant, central sympathomimetic, and apparent anxiolytic properties. Drug Dev Rev 8:135-145

Contreras PC, Rice KC, Jacobson AE, O'Donohue TL (1986): Stereotyped behaviour correlates better than ataxia with phencyclidine-receptor interactions. Eur J Pharmacol 121:9-18

Daly SA, Waddington JL (1993): Behavioural effects of the putative $\mathrm{D}_{3}$ dopamine receptor agonist 7-OH-DPAT in relation to other " $\mathrm{D}_{2}$-like" agonists. Neuropharmacology 32:509-510

Deutch AY, Tam S-Y, Freeman AS, Bowers MB, Roth RH (1987): Mesolimbic and mesocortical dopamine activation induced by phencyclidine: Contrasting pattern to striatal responses. Eur J Pharmacol 134:257-264

Deutch SI, Mastropaolo J, Schwartz BL, Rosse RB, Morihisa JM (1989): A "glutamatergic hypothesis" of schizophrenia. Clin Neuropharmacol 12:1-13

Ford LM, Norman AB, Sanberg PR (1989): The topography of MK-801-induced locomotor patterns in rats. Physiol Behav 46:755-758

Freeman AS, Bunney BS (1984): The effects of phencyclidine and $\mathrm{N}$-allylnormetazocine on midbrain dopamine neuronal activity. Eur J Pharmacol 104:287-293

French ED, Vantini G (1984): Phencyclidine-induced locomotor activity in the rat is blocked by 6-hydroxy-dopamine lesion of the nucleus accumbens: Comparisons to other psychomotor stimulants. Psychopharmacology 82:83-88

French ED, Ceci A (1990): Non-competitive N-methyl-Daspartate antagonists are potent activators of ventral tegmental A10 dopamine neurons. Neurosci Lett 19:159-162

French ED, Pilapil C, Quirion R (1985): Phencyclidine binding sites in the nucleus accumbens and phencyclidineinduced hyperactivity are decreased following lesions of the mesolimbic dopamine system. Eur J Pharmacol 116: 1-9

French ED, Ferkany J, Abreu M, Levenson S (1991): Effects of competitive $\mathrm{N}$-methyl-D-aspartate antagonists on midbrain dopamine neurons: An electrophysiological and behavioural comparison to phencyclidine. Neuropharmacology 30:1039-1046

Gasic GP, Hollmann M (1992): Molecular neurobiology of glutamate receptors. Annu Rev Physiol 54:507-536

Goodwin P, Starr BS, Starr MS (1992): Motor responses to dopamine $D_{1}$ and $D_{2}$ agonists in the reserpine-treated mouse are affected differentially by the NMDA receptor antagonist MK 801. J. Neural Transm 4:15-26

Hall H, Sällemark M, Jerning E (1986): Effects of remoxipride and some related new substituted salicylamides on rat brain receptors. Acta Pharmacol Toxicol 58:61-70

Hiramatsu M, Cho AK, Nabeshima T (1989): Comparison of the behavioral and biochemical effects of the NMDA receptor antagonists, MK-801 and phencyclidine. Eur J Pharmacol 166:359-366

Hoffman DC (1992): Typical and atypical neuroleptics an- 
tagonize MK-801-induced locomotion and stereotypy in rats. J Neural Transm 89:1-10

Hollander M, Wolfe DA (1973): Nonparametric statistical methods. Wiley, New York.

Hyttel J (1978): Effects of neuroleptics on ${ }^{3} \mathrm{H}$-haloperidol and ${ }^{3} \mathrm{H}$-cis(Z)-flupenthixol binding and adenylate cyclase activity in vitro. Life Sci 23:551-556

Imperato A, Scrocco MG, Bacchi S, Angelucci L (1990): NMDA receptors and in vivo dopamine release in the nucleus accumbens and caudatus. Eur J Pharmacol 187:555-556

Javitt DC, Zukin SR (1991): Recent advances in the phencyclidine model of schizophrenia. Am J Psychiatry 148: 1301-1308

Johnston KM (1987): Phencyclidine: behavioural and biochemical evidence supporting a role for dopamine. Fed Proc 42:2579-2583

Johnston KM, Jones SM (1990): Neuropharmacology of phencyclidine: Basic mechanisms and therapeutic potential. Annu Rev Pharmacol Toxicol 30:707-750

Kashihara K, Hamamura T, Okumura K, Otsuki S (1990): Effect of MK-801 on endogenous dopamine release in vivo. Brain Res 528:80-82

Kim JS, Kornhuber HH, Schmid-Burgk W, Holzmuller B (1990): Low cerebrospinal fluid glutamate in schizophrenic patients and a new hypothesis on schizophrenia. Neurosci Lett 20:379-382

Koek W, Woods JH, Winger GD (1988): MK-801, a proposed non-competitive antagonist of excitatory amino acid neurotransmission, produces phencyclidine-like behavioural effects in pigeons, rats and rhesus monkeys. J Pharmacol Exp Ther 245:969-974

Köhler C, Hall H, Ögren SO, Gawell L (1985): Specific in vitro and in vivo binding of ${ }^{3} \mathrm{H}$-raclopride. A potent substituted benzamide drug with high affinity for dopamine $\mathrm{D}_{2}$ receptors in the rat brain. Biochem Pharmacol 34: 2251-2259

Köhler C, Radesäter AC, Karlsson-Boethius G, Bryske B, Widman $M$ (1992): Regional distribution and in vivo binding of the atypical antipsychotic drug remoxipride. A biochemical and autoradiographic analysis in the rat brain. J Neural Transm 87:49-62

Lévesque D, Diaz J, Pilon C, Martres MP, Giros B, Souil E, Schott D, Morgat JL, Schwartz JC, Sokoloff P (1992): Identification, characterization, and localization of the dopamine $D_{3}$ receptor in rat brain using $7-\left[{ }^{3} \mathrm{H}\right]$ hydroxyN,N,-di-n-propyl-2-aminotetralin. Proc Natl Acad Sci USA 89:8155-8159

Liljequist S, Ossowska K, Grabowska-Andén M, Andén N-E (1991): Effect of the NMDA receptor antagonist, MK-801, on locomotor activity and on the metabolism of dopamine in various brain areas of mice. Eur J Pharmacol 195:55-61

Lillrank SM, O'Connor WO, Ungerstedt U (1991): The effects of phencyclidine on neurotransmitter release from the dorsolateral striatum of awake moving rats. In Rollema H, Westerink BHC, Drijthout WJ (eds), Monitoring molecules in neuroscience, Noordwijkerhout, Proceedings of 5 th International Conference on in vivo methods. Sept. 21-24, The Netherlands, pp 98-101

Lodge D, Davies SN, Jones MG, Miller J, Mannalack DT, Ornstein PL, Verberne AJM, Young N, Beart PM (1988): A comparison of the in vitro and in vivo activity of five potent and competitive NMDA antagonists. Br J Pharmacol 95:957-965

Löscher W, Annies R, Hönack D (1991): The N-methyl-Daspartate receptor antagonist MK-801 induces increases in dopamine and serotonin metabolism in several brain regions of rats. Neurosci Lett 128:191-194

Luby ED, Cohen BD, Rosenbaum G, Gottlieb JS, Kelley R (1959): Study of a new schizophrenomimetic drugSernyl. Arch Neurol Psychiatry 81:363-369

Martin GE (1986): Catecholamine release within the striatum of the freely moving rat. Ann NY Acad Sci 473:151-159

McKinney WT (1989): Animal models of schizophrenic disorders. In Schulz SC, Tamminga CA (eds), Schizophrenia: Scientific Progress, Oxford University Press, New York, pp 141-154

Mohell NA, Sällemark M, Rosqvist S, Malmberg ÄH, Jackson DM (1993): Binding characteristics of remoxipride and its metabolites to dopamine $\mathrm{D}_{2}$ and $\mathrm{D}_{3}$ receptors. Eur J Pharmacol 238:121-125

Monaghan DT, Bridges RJ, Cotman CW (1989): The exitatory amino acid receptors: their classes, pharmacology, and distinct properties in the function of the central nervous system. Annu Rev Pharmacol Toxicol 29:365-401

Morari M, O'Connor WT, Ungerstedt U, Fuxe K (1993): $\mathrm{N}$-methyl-D-aspartic acid differentially regulates extracellular dopamine, GABA and glutamate levels in the dorsolateral striatum of the halothane-anaesthetized rat: An in vivo microdialysis study. J Neurochem 60:1884-1895

Murase S, Mathé JM, Grenhoff J, Svensson TH (1993): Effects of dizocilpine (MK-801) on rat midbrain dopamine cell activity: Differential actions on firing pattern related to anatomical localization. J Neural Transm 91:13-25

Ögren SO, Köhler C, Fuxe K, Ängeby K (1979): Behavioural effects of ergot drugs. In Fuxe K, Calne DB (eds), Dopamine ergot derivatives and motor function. Oxford, Pergamon Press, pp 187-205

Ögren SO, Hall H, Köhler C, Magnusson O, Lindbom L-O, Ängeby K, Florvall L (1984): Remoxipride, a new potential antipsychotic compound with selective antidopaminergic actions in the rat brain. Eur J Pharmacol 102:459-474

Ögren SO, Hall H, Köhler C, Magnusson O, Sjöstrand SE (1986): The selective dopamine $D_{2}$ receptor antagonist raclopride discriminates between dopamine-mediated motor functions. Psychopharmacology 90:287-294

Ögren SO, Florvall L, Hall H, Magnusson O, Ängeby-Möller K (1990): Neuropharmacological and behavioural properties of remoxipride in the rat. Acta Psychiatr Scand 82 (Suppl. 358) 82:21-26

Ögren SO, Thyréen G, Lindeberg A, Amkéus E (1994a): Remoxipride and other dopamine receptor antagonists in two tests of catalepsy in the rat. Comparison with dopamine receptor functions in the striatum. Psychopharmacology. Submitted.

Ögren SO, Rosén L, Fuxe K (1994b): The dopamine $D_{2}$ antagonist remoxipride acts in vivo on a subpopulation of dopamine $\mathrm{D}_{2}$ receptors. Neuroscience 61:269-283

Ouagazzal A, Nieoullon A, Amalric M (1993): Effects of dopamine $D_{1}$ and $D_{2}$ receptor blockade on MK-801-induced hyperlocomotion in rats. Nauyn-Schmideberg's Arch Psychopharmacology 111:427-434 
Pawlowski L, Mathé JM, Svensson TH (1990): Phencyclidine activates rat $\mathrm{A} 10$ dopamine neurons but reduces burst activity and causes regularization of firing. Acta Physiol Scand 139(3):529-530

Raffa RB, Ortegon ME, Robisch DM, Martin GE (1989): In vivo demonstration of the enhancement of MK- 801 by L-glutamate. Life Sci 44:1593-1599

Rao TS, Kim HS, Lehmann J, Martin LL, Wood PL (1990): Selective activation of dopaminergic pathways in the mesocortex by compounds that act at the phencyclidine (PCP) binding site: Tentative evidence for PCP recognition sites not coupled to N-methyl-D-aspartate (NMDA) receptors. Neuropharmacology 29:225-230

Reid AA, Mattson MV, de Costa BR, Thurkauf A, Jacobson AE, Monn JA, Rice KC, Rothmann RB (1990): Specificity of phencyclidine binding sites in guinea pig brain. Neuropharmacology 29:811-817

See RE, Sorg BA, Chapman MA, Kalivas PW (1991): In vivo assessment of release and metabolism of dopamine in the ventrolateral striatum of awake rats following administration of dopamine $D_{1}$ and $D_{2}$ receptor agonists and antagonists. Neuropharmacology 30:1269-1274

Snell LD, Mueller ZL, Gannon RL, Silvermann B, Johnson $\mathrm{K}$ (1984): A comparison between classes of drugs having phencyclidine like behavioral properties on dopamine efflux in vitro and dopamine metabolism in vivo. J Pharmacol Exp Ther 231:261-269

Sokoloff P, Andrieux M, Besancon R, Pilon C, Martres MP, Giros B, Schwarts JC (1992): Pharmacology of human dopamine $\mathrm{D}_{3}$ receptor expressed in a mammalian cell line: Comparison with $\mathrm{D}_{2}$ receptor. Eur J Pharmacol 225:331-337

Ståhle L (1992): Do autoreceptors mediate dopamine agonist induced yawning and suppression of exploration? A critical review. Psychopharmacology 106:1-13
Sturgeon RD, Fessler RG, Meltzer HY (1979): Behavioural rating scales for assessing phencyclidine-induced locomotor activity, stereotyped behaviour and ataxia in rats. Eur J Pharmacol 59:169-179

Tiedtke PI, Bischoff C, Schmidt WJ (1990): MK-801-induced stereotypy and its antagonism by neuroleptic drugs. J Neural Transm 81:173-182

Titus RD, Kornfeld EC, Jones ND, Clemens JA, Smalstig EB, Fuller RW, Hahn RA, Hynes MD, Mason NR, Wong DT, Foreman MM (1983): Resolution and absolute configuration of an ergolene-related dopamine agonist, trans4,4a, 5,6,7,8,8a,9-octahydro-5-propyl-H(or 2H)-pyrazolo[3,4-g]-quinoline. J Med Chem 26:1112-1116

Tricklebank MD, Singh L, Oles RJ, Preston C, Iversen SD (1989): The behavioural effects of MK-801: a comparison with antagonists acting non-competitively and competitively at the NMDA receptor. Eur J Pharmacol 167:127-135

Tsuruta K, Frey EA, Grewe CW, Cote TE, Eskay RL, Kebabian JW (1981): Evidence that LY-141865 specifically stimulates the $\mathrm{D}_{2}$ dopamine receptor. Nature 292:463465

Werling LL, Jacocks III HM, McMahon PN (1990): Regulation of $\left[{ }^{3} \mathrm{H}\right]$ dopamine release from guinea pig striatum by NMDA receptor/channel activators and inhibitors. J Pharmacol Exper Ther 255:40-45

Willets J, Balster RL, Leander D (1990): The behavioral pharmacology of NMDA receptor antagonists. Trends Pharmacol Sci 11:423-428

Wong EHF, Kemp JA (1991) Sites for antagonism on the N-methyl-D-aspartate receptor channel complex. Ann Rev Pharmacol Toxicol 31:401-425

Wong EHF, Kemp JA, Priestly T, Knight AR, Woodruff GN, Iversen LL (1986): The anticonvulsant MK-801 is a potent N-methyl-D-aspartate antagonist. Proc Natl Acad Sci USA 83:7104-7108 